\title{
The service function as a holistic management concept
}

\author{
Christian Kowalkowski
}

\section{Linköping University Post Print}

\section{N.B.: When citing this work, cite the original article.}

Original Publication:

Christian Kowalkowski, The service function as a holistic management concept, 2011, The journal of business \& industrial marketing, (26), 7, 484-492. http://dx.doi.org/10.1108/08858621111162280

Copyright: Emerald

http://www.emeraldinsight.com/

Postprint available at: Linköping University Electronic Press

http://urn.kb.se/resolve?urn=urn:nbn:se:liu:diva-70494 


\title{
The service function as a holistic management concept
}

\author{
Christian Kowalkowski \\ Department of Management and Engineering \\ Linköping University \\ 581 83, Linköping, Sweden \\ Email: christian.kowalkowski@liu.se \\ Phone: +46-13-281571
}

\begin{abstract}
Purpose of the paper
\end{abstract}

This article introduces the service function concept, as well as why and how it can be a useful concept for addressing service management challenges in industrial firms.

\section{Design/methodology/approach}

Two in-depth case studies of global industrial firms enabled a thorough understanding of the roles of the service function entities and interdependencies between them.

\section{Findings}

Although the service organization is most likely the key entity, it is only one part of the service function; other organizational entities are to be seen as part-time service functions.

\section{Research limitations/implications}

A finer-grained conceptualization would enable a better understanding of the front- and backoffice entities involved in the service processes.

\section{Practical implications}

The concept can be useful when communicating the importance of services and the interrelatedness between the service organization and other parts of the firm, which generates better internal understanding of the service processes. The alignment between service offering 
and organization can be elaborated by mapping where service development, sales, and production take place, what the ideal configuration would be, and the roles played by different parts of the service function.

Originality/value of the paper

The service function is a novel concept and is particularly relevant for industrial firms that offer services. It highlights the fact that it is erroneous to equate services with the activities of the service organization. Instead, a more holistic approach to the management of service offerings is needed.

Type of paper: Conceptual

Keywords: Service function, service organization, industrial services, manufacturing

Christian Kowalkowski, $\mathrm{PhD}$, is Assistant Professor of Industrial Marketing at Linköping University, Sweden. His research focuses on service logic, service infusion in manufacturing firms, dynamic capabilities, and value co-creation strategies. He can be contacted at christian.kowalkowski@liu.se. 


\section{Introduction}

Over the past decade, a growing amount of attention has been paid to service offerings in manufacturing, information technology, and other non-service sectors around the world. This phenomenon is often described as a goods-services transition, in which firms such as Caterpillar, Ericsson, Huawei, Siemens, and Tata have increased their provision of services. The phenomenon is often ascribed to industry commoditization, which is characterized by increasing homogeneity of products, higher price sensitivity among customers, and lower switching costs (Reimann et al., 2010); it is also ascribed to opportunities to achieve competitive advantage through closer customer relationships and higher profit margins (e.g., Gebauer and Friedli, 2005; Jacob and Ulaga, 2008; Matthyssens and Vandenbempt, 2008; Raddats and Easingwood, 2010). The increasing strategic importance of service offerings to market-leading industrial firms has made the ability to manage the service business in a manufacturing context ever more vital (Kowalkowski et al., 2011a; 2011b).

Furthermore, the differences between an industrial, goods-dominant business logic and a coproduction/creation, service-dominant business logic (Kingman-Brundage et al., 1995; Normann, 2001; Ramírez, 1999; Vargo and Lusch, 2008) have made it particularly interesting to investigate the management of firms that produce goods as well as services. As Mathieu (2001) noted, "because of the specificity of service management, it is not that easy, nor natural, for a manufacturing firm to carry out a service strategy" (p. 451).

It is pertinent, therefore, to investigate the service function within industrial firms that produce both goods and services. In this context, service function includes not only the service organization, but also other organizational units that, either directly or indirectly, have a role in the service development, sales, delivery, and renewal processes (Kowalkowski, 2008). The rationale for the service function concept is that it is not sufficient to limit analysis of the service management of industrial firms to the service organization only. For example, in order 
to implement a successful and deliberate service strategy in industrial firms, all areas of the firm affected by service strategy must be involved in the service development process, which integrates competences that exist within the firm, but outside the service organization (Gebauer et al., 2005; Kindström and Kowalkowski, 2009). This highlights the need to look beyond the service organization. In this way, the service function parallels Gummesson's (1995) marketing function concept; even if the marketing organization undoubtedly plays a central role, several other organizational entities also play critical roles as part-time marketers of the firm (Gummesson, 1987; 1991). The fact that industrial services span a wide range of offerings, from basic after-sales services to process-orientated solutions that involve services and capital goods (Kowalkowski et al., 2011a), is likely to have consequences on the service function of the firm.

Against this background, the present paper focuses on two primary objectives. The first is to describe the service function concept and its components. The second is to discuss why and how the service function can be a useful concept with which to address some of the challenges of managing services in industrial firms.

The research inquiry can be characterized as being mainly explorative and comparative. The empirical evidence has come predominantly from case studies of two market-leading firms ITT Water \& Wastewater and Toyota Material Handling - and some of their European customers. The phenomenon studied is a repositioning in moderately dynamic markets of firms' value propositions towards increased service provision. The case study was chosen as a research design in order to attain a deeper research understanding of the thinking-doing processes of members of the service function (Woodside and Wilson, 2003). The iterative process between theory and empirical data collection made it possible to match theory with reality, thereby taking advantage of the systemic characteristics of both the empirical world and the theoretical models (Dubois and Gadde, 2002; Matthyssens and Vandenbempt, 2003). 


\section{Theoretical background}

It has been argued that, in order to achieve successful service management, firms should adopt a multidimensional, holistic approach that does not separate service development from service production and within which the customer interface and new technology are both taken into account (den Hertog et al., 2010; Kindström and Kowalkowski, 2009). Thus, even if the service function is generally regarded as the (local and/or central) organizational entity that is responsible for the firm's main service activities, it is not sufficient to only investigate the service organization of the industrial firm. The industrial firm may not even have an inhouse service organization. For instance, many firms operate through dealers or collaborate with partner firms responsible for the service production. Likewise, the service function must not be seen in isolation from other organizational functions. As defined in this paper, the service function only concerns the management of services that are offered, locally and globally, to external customers in an industrial business-to-business context. In other words, it does not refer to any internal services and support organizations.

In order to better understand the service function concept, the following section outlines Gummesson's $(1987 ; 1991)$ part-time marketing concept, upon which the service function concept is based.

\section{The role of part-time service functions}

Gummesson $(1987 ; 1991)$ coined the term 'part-time marketers' to refer to all employees who are not full-time marketers; that is, employees who are not marketing specialists from marketing and sales departments, but who do carry out marketing activities and thereby influence customer satisfaction, customer perceived quality, and revenue. For example, parttime marketers include front-line personnel working with the production of different services. Such part-time marketers not only outnumber full-time marketers in most industrial markets several times over, but they are often the only personnel and, therefore, the only marketers. 
Similarly, part-time service employees include all those employees who work in other organizational entities, but still have a direct or indirect effect on the firm's service offering. Established internal relationships are essential for the success of part-time service employees and the management of customer relationships.

Furthermore, the vital role of the customer in service innovation (Gallouj and Weinstein, 1997; Mannervik and Ramírez, 2006) and service production (Bitner et al., 1997; Grönroos, 2006; Normann, 2001) makes it necessary to recognize that customers are also part of the service function. Although it can be beneficial to have customers involved in the service processes, it also increases input uncertainty, since the fact that customers are external to the firm means that they are more difficult to control (Larsson and Bowen, 1989). Service partners and other external resources in the business network that are involved in the service processes, either directly or indirectly, are also included in the service function. When, for instance, firms lack the capacity or the capability to perform the service efficiently or effectively, they tend to use service providers (Axelsson and Wynstra, 2002; Nordin, 2008).

\section{A dynamic and interconnected function}

Industrial firms that undertake a strategic change in order to change their trajectory away from competing mainly through product leadership and attempt a transition downstream must develop new service capabilities, either organically or through acquisitions (Fang et al., 2008; Kindström, 2010). The decision to compete on industrial service offerings rather than merely on products is a strategic one (Homburg and Garbe, 1999) and when an industrial firm makes the decision to enhance its service offering, the character of the service function is likely to change.

An industrial firm that moves into the provision of complex services and integrated solutions, for example, must develop or acquire new competences, such as key account management and risk analysis skills (Brady et al., 2005). Changes of this nature may require connecting new 
specialist teams to the service function as part-time service entities or expansion of the service organization (that is, the full-time service function). This can result in the creation of new value configurations in which the patterns of co-production and, therefore, the roles of organizational entities differ from previous ones. In other words, depending on the offering, a firm has different market positions and requires different competences. This means that the structure of the service function is likely to differ (Kowalkowski, 2008).

Furthermore, the importance of developing trust and well-functioning relationships between participants in different parts of the service function means that well-functioning communication and dialogue are needed in order for the essential knowledge renewal processes to operate at the firm and employee level (Ballantyne, 2004). In addition, viewing service management and the service function from a holistic, systems theory perspective assumes that the whole does not equal the sum of its parts, that the parts depend on the system, and that knowledge is system dependent (Arbnor and Bjerke, 1997). This means that the interdependencies between the different parts of the service function must be understood, and also that their respective roles in the service processes affect the firm's service offering portfolio.

\section{Introducing the service function concept}

The literature on the transition from goods to services has noted that new forms of industrial offerings are associated with new organizational requirements (Davies, 2004; Galbraith, 2002; Gebauer and Kowalkowski, 2009). The achievement of competitive advantage through industrial services is largely derived from the firm's ability to create internal alignment among critical organizational elements in order to fit market needs (Kindström, 2010; Neu and Brown, 2008). Consequently, the organizational structure will differ depending on the firm's service offering portfolio, as well as on the type of customers, their disposition to participate in the service production process, and their inclination to invest in the customer-provider 
relationship. In order to manage industrial offerings strategically, it has been argued that firms should employ a holistic approach and look beyond the service organization (Gebauer et al., 2005; Kindström, 2010). As suggested above, one way to approach this issue is to use the service function concept.

A generic representation of the service function is given based on the empirical findings. This function not only includes the service organization and other internal entities, but also takes into account the role of the customer and the possible roles of various third-party actors in the business network with which the firm has relationships and, in various ways, influence the service offering (see Figure 1 for an example).

In analogy with Gummesson's (1995) marketing function, the shaded areas in Figure 1 represent the service function; that is, the service organization and parts of the firm other than the service organization, as well as external actors that are regarded as full-time or part-time service functions. However, the shadings should be seen not as quantified proportions, but rather as rough estimations that serve an illustrative purpose. Consequently, the shaded proportions between entities differ between firms and over time. In many industrial firms, the following distinct part-time service functions play an important role for the service operations.

Insert Figure 1 about here.

\section{Senior management}

Senior management formulates market strategies and targets, including service strategies and decisions about whether to reposition the firm on the marketplace through service offerings. In order to attain success in the service market, senior management must act as vocal champions for the required reorganization, and it must define clear and measurable servicerelated targets (Kindström, 2010). This also includes market communications, such as a 
CEO's statements towards employees or stakeholders. For example, the president of ITT Water \& Wastewater has articulated the transition into services in the corporate news magazine by stating that customers need total solutions and that customers and suppliers both stand to benefit from 'servitization.' The senior management of Toyota Material Handling has made similar statements, both internally and externally, arguing that "we are today essentially a service organization; it is the total service offering that is the key thing" (Kowalkowski, 2008). In addition, senior management is involved in the negotiations of major (service) contracts. Although decisions taken by senior management affect all forms of service operations, either directly or indirectly, senior management is particularly inclined to participate actively in international key account management (KAM) agreements due to their extent and importance.

\section{Sales}

Sales refers to the organizational units that are assigned to sell the firm's traditional offerings; in these cases, capital equipment. This entity is to be seen as an integral part of the service function and, apart from the service organization, is generally the most critical customerprovider interface for the service function. In fact, in a company with a significant rental business, the sales organization may even have the most important role of the service function because the sales force can provide customers with the option of either buying new equipment (i.e., ownership of goods) or a rental agreement (i.e., a service).

Companies with large service organizations tend to have their own dedicated sales force, as do those in which services represent a large proportion of total sales (Gebauer and Kowalkowski, 2009). In many cases, however, services are sold primarily through the product sales organization. A sales force with a traditional product-centric approach is likely to promote equipment sales at the expense of services, which often means giving away services in order to land a product deal (Anderson and Narus, 1995; Reinartz and Kumar, 2003). On 
the other hand, a sales force that has been trained and empowered to actively sell services may also offer service level agreements (SLAs) and other high-value services, which have positive effects on the service organization and the overall service function. In many markets where firms successfully sell services, the sales and service organizations work closely together, ideally in a symbiotic relationship, both on an operational and a managerial level. Hence, a well-functioning service-sales interface is regarded as vital, even if the local service organization has dedicated service salespeople.

\section{Key Account Management}

The role of Key Account Management can be similar to that of Sales, albeit on a more extensive level. Systematic planning, development of new offerings, and customer relationship management will lead to new business agreements (Homburg et al., 2002). Furthermore, it includes managing relationships with major national or international customers, which requires increased internal coordination. For international agreements, the local and central/regional KAM organization will be involved, and the latter will assign a central key account manager responsible for the specific deal (Brehmer and Rehme, 2009). As was the case with Toyota Material Handling, these large agreements may include not only equipment but also services. For key accounts that include services, the interface between KAM and the service organization becomes critical for the customer relationship.

\section{Finance}

Finance can have a decisive influence on a business deal, including those related to industrial services. Finance plays a supporting role for rental, KAM, and other industrial service activities. In the case of rental agreements and other extensive services in particular, financial guidelines and directives, as well as terms of payment, are key elements of the offering. These offerings are often associated with a higher financial risk than traditional equipment and services sales. Furthermore, even with a small amount of overlap or commonality between 
capital goods and financial services (Fang et al., 2008), financial services have been a highmargin, high-growth service for many industrial firms over the last decade, despite the steep downturn due to the recent, global financial crisis.

\section{Rental}

For firms that offer rental agreements, rental directly influences the customer relationship. Because they constitute a service, rental sales are regarded as a subset of service sales (Kowalkowski, 2008). If rental sales figures are quite modest, as are those of ITT Water \& Wastewater on many markets, the rental business of these sales companies may consist of salespeople who only work part-time with rentals. However, due to the specific characteristics and requirements of rentals, on an organizational level, they are generally separated from the service and sales organizations, both centrally and locally. This is the case for Toyota Material Handling, which has over 50 percent of its new trucks in long-term rental agreements in several markets. Nonetheless, many rental sales activities may be performed by the sales organization, particularly if the rental business is nascent. In addition, the service is usually performed by service technicians that belong to the service organization, although there may be specific technicians who only conduct rental-related service (this is a strategy that Toyota Material Handling carries out in some markets).

\section{Engineering and consulting}

Engineering/consulting can either be one organizational unit or several central and local units, depending on the firm. These units often have a focal role in service provision since they offer industrial services to the firm's customers. However, these services differ from (and complement) the traditional after-sales services that the service organization provides, as they require other specialist competences (such as process technical expertise) and focus on the customer's processes rather than on the installed base per se (Kowalkowski et al., 2011a). Process optimization, lifecycle cost calculations, and similar services can be essential if the 
firm wishes to enhance its service offering and compete on knowledge of customer processes. For example, ITT Water \& Wastewater offers specialist engineering services with which few other firms can compete. This is seen as a competitive advantage for repositioning the firm's offerings and developing customer relationships. For bundled, process-orientated offerings that require these competences, it becomes vital to manage the coordination and cooperation with the service organization and, therefore, to share knowledge across organizational boundaries.

\section{Product development}

$R \& D /$ product development mainly influences manufacturing and other parts of the traditional product organization. However, feedback loops from service personnel are important for designing equipment that is not only easy to assemble in the manufacturing plant, but also easy to replace in the field (Kindström and Kowalkowski, 2009). For example, the manner in which equipment is manufactured and integrated in the customer's processes affects such aspects as its accessibility and reparability. Therefore, when the construction team designs the equipment as part of the product development process, it can choose the extent to which it takes requests from the service organization into account. Depending on the design, ceteris paribus, the length of time required to repair the equipment can vary. In addition, requirements on material and manufacturing costs can affect the product quality and, consequently, affect the lifetime of the equipment and how often maintenance and repair activities are needed.

Issues like predictability of maintenance and lifecycle costs are essential, particularly for extensive services such as rental and performance-based contracts. This calls for intra-firm collaboration between the service organization and the product development organizations (Kowalkowski, 2010). Furthermore, because services are increasingly information-based (Rust and Thompson, 2006), the technology being bundled into the equipment must support 
ICT systems and applications used for service provision and vice versa. Since the organizational dividing line between the service organization and the technical department(s) is often relatively distinct, it can be difficult for product development to understand the needs of the service organization and, thus, to take the requirements into account in the product development processes.

\section{Manufacturing}

Manufacturing influences the customer relationship through capital equipment and, indirectly, influences the service function. For example, the use of cheaper components can lower the product price, but if this result in lower quality equipment, it will lead to more frequent repair and maintenance (Kowalkowski, 2010). From a short-term perspective, provided the firm's revenue models are based on traditional after-sales services (that is, that the customer pays for service hours and spare parts), this can have a positive effect on service sales and utilization of service personnel. In the longer term, however, it can cause the deterioration of customer relationships and hinder the firm's margins on more extensive offerings with other forms of revenue models. Nevertheless, the opportunities to replace physical components for a product design that is currently being manufactured vary significantly between products and industries. Whereas it is relatively straightforward to replace the driving wheels on a warehouse truck to ones of higher quality, replacing components on an aircraft engine is a fundamentally different task that involves high costs, new certification processes, etc. Furthermore, on a strategic level, firms must decide whether new goods and services should be linked through bundling (Johansson and Olhager, 2006).

\section{External service functions}

Among the external actors, customers obviously have the central role; as the main participants in the service co-creation process (Grönroos, 2006; Normann, 2001), they are included in the service function. Since the focus of this study is on the service function of the provider, the 
customer is generally reduced to one entity, as in Figure 1. Although the situation differs between firms and geographical markets, third-party service providers have an evident role in a generic representation of the service function. For example, ITT Water \& Wastewater relies, to varying degrees, on external service partners in most of its local markets. Whereas Toyota Material Handling has internal service organizations in most European markets, its US branch, Raymond, operates through external service partners. External service providers can also be firms other than authorized and unauthorized service partners (that is, direct competitors). What is particularly evident for some sales companies is the role that other actors in the business network, such as IT suppliers and sub-system integrators, have on the service offerings. For ITT Water \& Wastewater, consultants and contractors often have a significant influence on specifications and inquiries, which means that these network relationships must be managed in accordance with the firm's market and service strategies. Extensive offerings, such as integrated solutions, require particularly intense business network cooperation, which corresponds to the findings of Cova and Salle (2008) and Matthyssens and Vandenbempt (2008).

\section{Interdependencies between service function entities}

Despite the role that part-time service functions play for service management, the main locus of interdependencies for many services is only one or a few organizational entities of the service function. In line with Larsson and Bowen (1989), depending on the type of service, different interdependencies - and, therefore, different organizational arrangements - are required. With more extensive SLAs, the number of customer interfaces increases and it becomes essential to emphasize other values, such as 'peace of mind,' rather than specifying only the frequency of visits, hourly costs, and spare parts prices. As SLAs become more extensive and process-oriented, pricing tends to move from variable to a fixed, based on a certain period of time (Kindström, 2010; Kowalkowski, 2008). In order to offer these 
services, it is necessary to have additional competences, which do not reside in the service organization. Consequently, sales, KAM, engineering/consulting, and other part-time service functions will have a more prominent role in the organizational arrangement for bundled, process-orientated offerings, such as ITT Water \& Wastewater's customized SLAs and Toyota Material Handling's long-term rental agreements. Rental services, for example, can be organized quite differently depending on factors such as the type of equipment being rented, the size of the agreement, whether any additional services are bundled to it, and the service infrastructure.

Depending on the phase, the service development and production processes involve different local and/or central organizational entities (both full-time and part-time service functions). For example, during the development of an ICT-based service at ITT Water \& Wastewater, central service managers and central/local engineering teams, such as monitoring and control entities, may be the parties that are primarily involved. During the take-to-market and sales processes, it is mostly the local sales or service organizations that are involved, after initial support, training, and marketing material from the central marketing organization. Once the offering is sold, it is deployed and later serviced by the local service organization, together with local monitoring and control specialists. In the customer relationship between Toyota Material Handling and its major rental customers in the UK, different parts of the service function are involved in different phases of the process. For instance, representatives from the service and sales organizations are generally involved when (re-)selling a rental agreement. After the implementation phase, this responsibility is handed over to the KAM that will be managing the customer relationship, although the customer will also have regular meetings with other full-time and part-time service functions (mainly service and sales).

The interdependencies between the entities of the service function not only differ between firms, but they also differ in importance, depending on the firm's service offering portfolio. 
Particularly in the case of major service development projects for bundled, process-orientated offerings, the adaptation of a multiple and flexible structure is seen as advantageous. This form of 'contingent hierarchy' encourages reciprocity among service function entities and is likely to lead to better overall responsiveness to customer demand (Tuli et al., 2007). In some situations, a high degree of local responsiveness is decisive, whereas efficient central processes may play a more prominent role in other cases. Therefore, authority and status should be allocated to the entity that knows how to orchestrate organizational resources to best facilitate value creation (Kingman-Brundage et al., 1995).

\section{The central-local dimension}

If manufacturing is regarded as a central activity, all organizational entities in Figure 1 can be found on the central level in the case companies. With the exception of manufacturing and product development, all entities can also be found locally in the sales companies. However, not all functions necessarily exist in all subsidiaries. Besides, as is the case with ITT Water \& Wastewater case, in some markets where rentals are not yet strong, the rental activities may be performed by service managers with part-time responsibility for rentals. In addition, if a firm has not focused on rentals previously, local demand on a leading market could lead a sales company to offer rental agreements despite the lack of central rental organization and strategies. If this is successful, rental could be brought to central management's agenda in a

second phase as well. Consequently, managing the interdependencies within multinational firms (that is, the degrees of centralization/decentralization and integration) (Siggelkow and Levinthal, 2003), becomes a critical aspect for firms looking to expand their service offerings across borders.

\section{Extending the service function}

As discussed, enhanced service offerings may require new service function structures, and therefore new skills and interdependencies between organizational entities. This should also 
have consequences for the product-related side of the organization; by keeping the product and service businesses completely separate, the firm risks losing out on the linkages and strategic relationships between the two areas (Baveja et al., 2004). For example, isolating the service operations and personnel from product-related operations can hinder the company's ability to access its full complement of intra-firm capabilities and resources, which it needs in order to offer complex services, as it is vital to be able to integrate competences from different organizational units and cultivate intra-firm collaboration (Neu and Brown, 2008).

This view is supported by Brann et al. (2005) and Kowalkowski et al. (2011a), who suggested that the degree of intra-firm collaboration and integration of goals is contingent on the type of service. It may be beneficial to manage traditional after-sales services through a clearer and more distinct service organization, whereas more extensive, process-orientated services require more integration with other parts of the service function. Therefore, during a transition from basic services to integrated solutions, the traditional service organization shifts from being the main locus of the service function to being just one part of it. In other words, rather than correlating the only service organization with the firm's service strategies, the other parts of the service function should also be taken into account when managing the service business.

\section{Conclusions and implications}

This study's main theoretical contribution is the service function concept. The study highlights the fact that it is erroneous to equate services with the deeds, processes, and performances of the service organization. Instead, this paper argues the need for a more holistic approach to the management of service offerings, and that although the service organization is most likely the key entity, it is only one subset of the service function. In addition, with industrial firms offering more than just after-sales services, the capabilities of specific part-time service functions become decisive for the market success of many new service offerings. 
Hence, the traditional service organization shifts from being the main locus of the service function to simply one part of it. For example, if an industrial service provider changes its business model and become a systems integrator, most of the core capabilities would not reside in the traditional service organization (Brady et al., 2005; Davies et al., 2007). Although the service organizations in the cases studied have remained the main locus of the service function, due to the type of services offered (i.e., most emphasis on maintenance, repair, and related after-sales activities in SLAs and rental agreements), success in the marketplace is increasingly based on factors outside the service organization, and those that are to be formed in other parts of the service function. Thus, in order to have a competitive service offering, the firm must think in terms of wholes and in terms of integration of structure (i.e., service function) and processes (cf. Normann, 1983). It is not enough to limit the discussion to the service organization. The need for increased integration between service function entities is supported by Neu and Brown (2008), who found that an autonomous structural form did not support the intent to satisfy highly complex needs.

Unless the service function adapts to new offerings with new requirements regarding competence, there is a risk of a structure-strategy misalignment between the organizational arrangement of the service function and the market strategy (Gebauer et al., 2010). In line with Normann's (2001) thoughts on value creation and sources of competitive advantage, the firm must have a strategic renewal capability in order to reconfigure its service function and service offering. The effective knowledge creation and renewal processes in vertical relations between employees and management, as well as in collaborative horizontal relations between service function entities, require trust and collaboration. An increasing number of offerings, generally the strategically most important ones, depend on efficient horizontal and vertical coordination within the service function. This makes it vital to have a corporate culture that creates and cultivates trust between local and central organizational entities (cf., Grönroos, 
2007). For this purpose, formal structures are essential, but so too are various forms of informal forums (Ghoshal and Nohria, 1989). Such informal structures may complement more rigid, formal structures and facilitate socialization between local and central service entities, as well as between local service entities from different countries (Kowalkowski et al., 2011a). Another strategic matter for the firm is how it should manage the service offering portfolio; that is, to say what service offerings and organizational arrangements it should have. The service organization can sufficiently manage many traditional after-sales services on its own, but for more complex services the service organization is likely to either require support from specialist (part-time service) functions or the specialist function may be the main locus of service interactions. The latter would be the case with systems engineering services, where there are few interactions with the traditional (after-sales) service organization. Thus, as firms increasingly compete through (complex) service offerings, the importance of cross-functional collaboration for competitive offerings grows. The firm must make certain choices that have consequences for its competitive advantage and how its service function is organized. These include whether the firm focuses on after-sales services, rental, or consulting, whether it emphasizes customer relationships or product features, and whether it acts reactively or proactively to exogenous changes.

\section{Limitations and future research lines}

This study has certain limitations. When suggesting and discussing the service function concept, the central-local dimension has not been thoroughly considered. This was a deliberate choice, made in order to simplify the elements that make up the service function. However, since most major firms have an international presence, there are also aspects related to the central-local interface of the service function that are relevant. A more fine-grained conceptualization of the service function would include not only the central-local dimension, but also the central and local front and back office entities involved in the service processes 
(cf., Larsson and Bowen, 1989). In addition, future research could investigate the roles of the service function entities in different phases of the service process, such as the negotiation phase (including bargaining), the commitment phase (including the formal legal contractual), and the operational (execution) phase (cf., Ring and van de Ven, 1994). Finally, given the interest in exploring what organizational capabilities and strategies are required for an increased service offering scope, future studies could analyze which organizational configurations fit more or less with which service offerings portfolios.

\section{Managerial implications}

For managers, the service function concept can be useful when communicating the importance of services and the interrelatedness between the service organization and other parts of the firm. Such an understanding could create a better awareness of the 'big picture' and of the restructuring and cultural change that may need to take place if the service business is to be a revenue growth engine for the firm. This is especially important in major service development, sales, and delivery projects in which various forms of contingent hierarchies play a central role (Tuli et al., 2007). In such multiple and flexible organizational structures, the design of the service function differs depending on the project phase, and well-functioning collaboration between the service function entities is particularly critical. For example, discussions about the interdependencies between organizational entities can be held in local workshops involving members from different departments. Members from various full-time and part-time service functions could be involved, depending on the structure of the organization, the roles of various part-time service functions, and the service strategies of the firm.

If, for example, a majority of services are sold locally through the (product) sales organizations, it may be worth involving local salespeople and service technicians in service function workshops in order to increase the mutual understanding of the roles of both parties 
(actual and potential) in the service sales and production processes, and also to improve the collaboration between the two. Likewise, in order to better coordinate the service portfolio, which is particularly vital when offering bundled services, employees in charge of different services - from traditional after-sales services to process-oriented engineering and consulting services - should meet and discuss targets and strategies. Designing for the service market in product development projects (for example, serviceability, maintainability, and legal demands) requires closer collaboration and better understanding between service development and product development entities. In particular, service issues tend to have a lower priority on managers' agenda, which often results in inadequate budget allocation, insufficient representation in decision-making forums such as steering groups, involvement in late stages of development projects, and product centricity rather than customer centricity. Better internal understanding and leverage of services can overcome these barriers.

Operational-level employees and managers may both participate in discussions on the service function concept, depending on the purpose. However, regardless of whether the service function is mainly central or local and whether the central or local organization drives the firm's service business development, firms can 'lubricate' the process through the commitment of senior management and centrally distributed resources.

Furthermore, the service function concept can complement existing approaches to service development and management, such as service blueprinting (Bitner et al., 2008; Fließ and Kleinaltenkamp, 2004). However, instead of depicting the steps and components in the service production process, managers can map where service development, sales, and production takes place, what the ideal state, if any, would be, and the indirect roles of the other parts of the function. This would help elaborate the alignment between service offering and organization. For such purposes, it may be suitable to further break down the service function entities to central and local ones as well as to separate front office and back office. 
Finally, a related issue is how to define the service business of the firm and how to measure the revenues and value of services. Perhaps surprisingly, even market-leading industrial firms may be unable to accurately measure their service operations on local markets; this inhibits a comparison of performance and revenues between markets and analysis of performance metrics on an aggregated level. Industrial services are not only traditional after-sales services; they also include technical consulting, rental sales, and other services for which parts of the service function other than the service organization plays a critical role. Therefore, the firm must have a clear service strategy and purpose for enhancing its service offering. In other words, the firm must decide if it is only a strategic repositioning in order to support increased product and spare parts sales, or if it is part of a change of the firm's business model from manufacturer to service provider, which would imply that the firm's manufactured goods would no longer be the center of the firm's value proposition (Kindström, 2010; Kowalkowski, 2010). In either case, the choice has consequences for managing the service function, although the consequences are very different.

\section{References}

Anderson, J.C. and Narus, J.A. (1995), "Capturing the Value of Supplementary Services", Harvard Business Review, Vol. 73 No. 1, pp. 75-83.

Arbnor, I. \& Bjerke, B. (1997) Methodology for Creating Business Knowledge, SAGE Publications, Thousand Oaks, USA.

Axelsson, B. and Wynstra, F. (2002), Buying Business Services. John Wiley \& Sons Ltd, West Sussex, UK.

Ballantyne, D. (2004), "Dialogue and its role in the development of relationship specific knowledge", Journal of Business \& Industrial Marketing, Vol. 19 No. 2, pp. 114-123.

Baveja, S.S., Gilbert, J. and Ledingham, D. (2004), "From Products to Services: Why It's Not So Simple", Harvard Management Update, Vol. 9 No. 4, pp. 3-5.

Bitner, M.J., Faranda, W.T., Hubbert, A.R. and Zeithaml, V.A. (1997), "Customer contributions and roles in service delivery", International Journal of Service Industry Management, Vol. 8 No. 3, pp. 193-205.

Bitner, M.J., Ostrom, A.L. and Morgan, F.N. (2008), "Service Blueprinting: A Practical Technique for Service Innovation”, California Management Review, Vol. 50 No. 3, pp. 6694. 
Brady, T., Davies, A. and Gann, D. (2005), "Creating value by delivering integrated solutions", International Journal of Project Management, Vol. 23 No. 5, pp. 360-365.

Brann, J.M., Oliva, R. and Gebauer, H. (2005), "Integrate or isolate? Impact of organizational structure on service performance in product manufacturing firms", paper presented at the $16^{\text {th }}$ Annual Conference of POMS, April 25-May 2, Chicago, IL.

Brehmer, P-O. and Rehme, J. (2009), "Proactive and reactive: drivers for key account management programmes", European Journal of Marketing, Vol. 43 Nos. 7-8, pp. 961-984.

Cova, B. and Salle, R. (2008). "Marketing solutions in accordance with the S-D logic: Cocreating value with customer network actors", Industrial Marketing Management, Vol. 37 No. 3, pp. 270-277.

Davies, A. (2004), "Moving base into high-value integrated solutions: a value stream approach", Industrial and Corporate Change, Vol. 13 No. 5, pp. 727-756.

Davies, A., Brady, T. and Hobday, M. (2007), "Organizing for solutions: Systems seller vs. systems integrator”, Industrial Marketing Management, Vol. 36 No. 2, pp. 183-193.

den Hertog, P., van der Aa, W., and de Jong, M.W . (2010), "Capabilities for managing service innovation: towards a conceptual framework", Journal of Service Management, Vol. 21 No. 4, pp. $490-514$.

Dubois, A. and Gadde, L-E. (2002), "Systematic combining: an abductive approach to case research”, Journal of Business Research, Vol. 55 No. 7, pp. 553-560.

Fang, E., Palmatier, R.W. and Steenkamp, J.B. (2008), "Effect of Service Transition Strategies on Firm Value", Journal of Marketing, Vol. 72 September, pp. 1-14.

Fließ, S. and Kleinaltenkamp, S. (2004), "Blueprinting the service company: Managing service processes efficiently", Journal of Business Research, Vol. 57, pp. 392-404.

Galbraith, J.R. (2002), “Organizing to Deliver Solutions”, Organizational Dynamics, Vol. 31 No. 2, pp. 194-207.

Gallouj, F. and Weinstein, O. (1997), “Innovation in services”, Research Policy, Vol. 26 Nos. 4/5, pp. 537-556.

Gebauer, H., Fleisch, E. and Friedli, T. (2005), "Overcoming the Service Paradox in Manufacturing Companies”, European Management Journal, Vol. 23 No. 1, pp. 14-26.

Gebauer, H. and Friedli, T. (2005), "Behavioral implications of the transition process from products to services", Journal of Business \& Industrial Marketing, Vol. 20 No. 2, pp. 70-78.

Gebauer, H. and Kowalkowski, C. (2009), "Customer-focused and service-focused orientation in organizational structures", paper presented at the $15^{\text {th }}$ CBIM Annual Academic Workshop, January 16-19, Atlanta, GA (forthcoming in Journal of Business \& Industrial Marketing (2012), Vol. 27 No. 3).

Gebauer, H., Edvardsson, B., Gustafsson, A. and Witell, L. (2010), "Match or mismatch: Strategy structure configurations in the service business of manufacturing companies", Journal of Service Research, Vol. 13 No. 2, pp. 198-215.

Ghoshal, S. and Nohria, N. (1989), "Internal differentiation within multinational corporations", Strategic Management Journal, Vol. 10 No. 4, pp. 323-337.

Grönroos, C. (2007), Service Management and Marketing - Customer Management in Service Competition (3rd ed.). John Wiley \& Sons Ltd, Chichester, UK. 
Grönroos, C. (2006), “What Can a Service Logic Offer Marketing Theory?” in Lusch, R.F. and Vargo, S.L. (Eds.), The Service-Dominant Logic of Marketing: Dialog, Debate, and Directions, Sharpe, New York.

Gummesson, E. (1987), “The new marketing - Developing long-term interactive relationships", Long Range Planning, Vol. 20 No. 4, pp. 10-20.

---- (1991), "Marketing-orientation Revisited: The Crucial Role of the Part-time Marketer", European Journal of Marketing, Vol. 25 No. 2, pp. 60-75.

---- (1995), Relationsmarknadsföring: Från 4P till 30R (Relationship Marketing: From 4Ps to 30Rs). Liber-Hermods, Malmö, Sweden.

Homburg, C. and Garbe, B. (1999), "Towards an Improved Understanding of Industrial Services: Quality Dimensions and Their Impact on Buyer-Seller Relationships", Journal of Business-to-Business Marketing, Vol. 6 No. 2, pp. 39-71.

Homburg, C., Workman, J.P. and Jensen, O. (2002), “A configurational perspective on key account management", Journal of Marketing, Vol. 66 No. 2, pp. 38-60.

Jacob, F. and Ulaga, W. (2008), "The transition from product to service in business markets: An agenda for academic inquiry", Industrial Marketing Management, Vol. 37 No. 3, pp. 247253.

Johansson, P. and Olhager, J. (2006), "Linking product-process matrices for manufacturing and industrial service operations", International Journal of Production Economics, Vol. 104 No. 2, pp. 615-624.

Kindström, D. (2010), “Towards a service-based business model - Key aspects for future competitive advantage”, European Management Journal, Vol. 28 No. 6, pp. 479-490.

Kindström, D. and Kowalkowski, C. (2009), "Development of industrial service offerings - A process framework”, Journal of Service Management, Vol. 20 No. 2, pp. 156-172.

Kingman-Brundage, J., George, W.R. and Bowen, D.E. (1995), “'Service logic': achieving service system integration", International Journal of Service Industry Management, Vol. 6 No. 4, 20-39.

Kowalkowski, C. (2008), Managing the Industrial Service Function, Doctoral dissertation, Linköping University, Sweden.

Kowalkowski, C. (2010), 'What does a service-dominant logic really mean for manufacturing firms?” CIRP Journal of Manufacturing Science and Technology, Vol. 3 No. 4, pp. 285-292.

Kowalkowski C., Kindström, D. and Brehmer, P-O. (2011a), "Managing industrial service offerings in global business markets", Journal of Business \& Industrial Marketing, Vol. 26 No 3, pp. 181-192.

Kowalkowski C., Kindström, D. and Witell, L. (2011b), "Internalisation or externalisation? Examining organisational arrangements for industrial services", Managing Service Quality, Vol. 21 No 4.

Larsson, R. and Bowen, D.E. (1989), "Organization and Customer: Managing Design and Coordination of Services," Academy of Management Review, Vol. 14 No. 2, pp. 213-233.

Mannervik, U. and R. Ramírez (2006), "Customers as Co-Innovators: An Initial Exploration of Its Strategic Importance”, in Edvardsson, B., Gustafsson, A., Kristensson, P., Magnusson, P. and Matthing, J. (Eds.), Involving Customers in New Service Development, Vol. 11. Imperial College Press, London. 
Mathieu, V. (2001), "Service strategies within the manufacturing sector: benefits, costs and partnership", International Journal of Service Industry Management, Vol. 12 No. 5, pp. 451475.

Matthyssens, P. and Vandenbempt, K. (2003), "Cognition-in-context: reorienting research in business market strategy”, Journal of Business \& Industrial Marketing, Vol. 18 Nos. 6/7, pp. 595-606.

---- (2008), "Moving from basic offerings to value-added solutions: Strategies, barriers and alignment”, Industrial Marketing Management, Vol. 37 No. 3, pp. 316-328.

Neu, W.A. and Brown, S.W. (2008), "Manufacturers forming successful complex business services: Designing an organization to fit the market", International Journal of Service Industry Management, Vol. 19 No. 2, 232-251.

Nordin, F. (2008), "Linkages between service sourcing decisions and competitive advantage: a review, propositions, and illustrating cases", International Journal of Production Economics, Vol. 114 No. 1, pp. 40-55.

Normann, R. (1983), Service Management. Almqvist \& Wiksell, Kristianstad, Sweden. ---- (2001), Reframing Business - When the Map Changes the Landscape. John Wiley \& Sons, Ltd., Chichester, UK.

Raddats, C. and Easingwood, C. (2010), "Services growth options for B2B product-centric businesses", Industrial Marketing Management, Vol. 39 No. 8, pp. 1334-1345.

Ramírez, R. (1999), "Value co-production: intellectual origins and implications for practice and research", Strategic Management Journal, Vol. 20 No. 1, pp. 49-65.

Reimann, M., Schilke, O. and Thomas, J. (2010), "Toward an understanding of industry commoditization: Its nature and role in evolving marketing competition", International Journal of Research in Marketing, Vol. 27 No. 2, 188-197.

Reinartz, W.J. and Kumar, V. (2003), “The Impact of Customer Relationship Characteristics on Profitable Lifetime Duration”, Journal of Marketing, Vol. 67 No. 1, 77-99.

Ring, P.S. and van de Ven, A.H. (1994), "Developmental Processes of Cooperative Interorganizational Relationships", Academy of Management Review, Vol. 19 No. 1, 90-118.

Rust, R.T. and Thompson, D.V. (2006), "How does marketing strategy change in a servicebased world? Implications and directions for research", in Lusch, R.F. and Vargo, S.L. (Eds.), The Service-Dominant Logic of Marketing: Dialog, Debate, and Directions. M.E. Sharpe, Armonk, NY.

Siggelkow, N. and Levinthal, D.A. (2003), "Temporarily Divide to Conquer: Centralized, Decentralized, and Reintegrated Organizational Approaches to Exploration and Adaptation", Organizational Science, Vol. 14 No. 6, pp. 650-669.

Tuli, K.R., Kohli, A.K. and Bharadwaj, S.G. (2007), "Rethinking Customer Solutions: From Product Bundles to Relational Processes", Journal of Marketing, Vol. 71 July, pp. 1-17.

Vargo, S.L. and Lusch, R.F. (2008), "From goods to service(s): Divergences and convergences of logics", Industrial Marketing Management, Vol. 37 No. 3, pp. 254-259.

Woodside, A.G. and Wilson, E.J. (2003), "Case study methods for theory building”, Journal of Business \& Industrial Marketing, Vol. 18 Nos. 6/7, 493-508. 


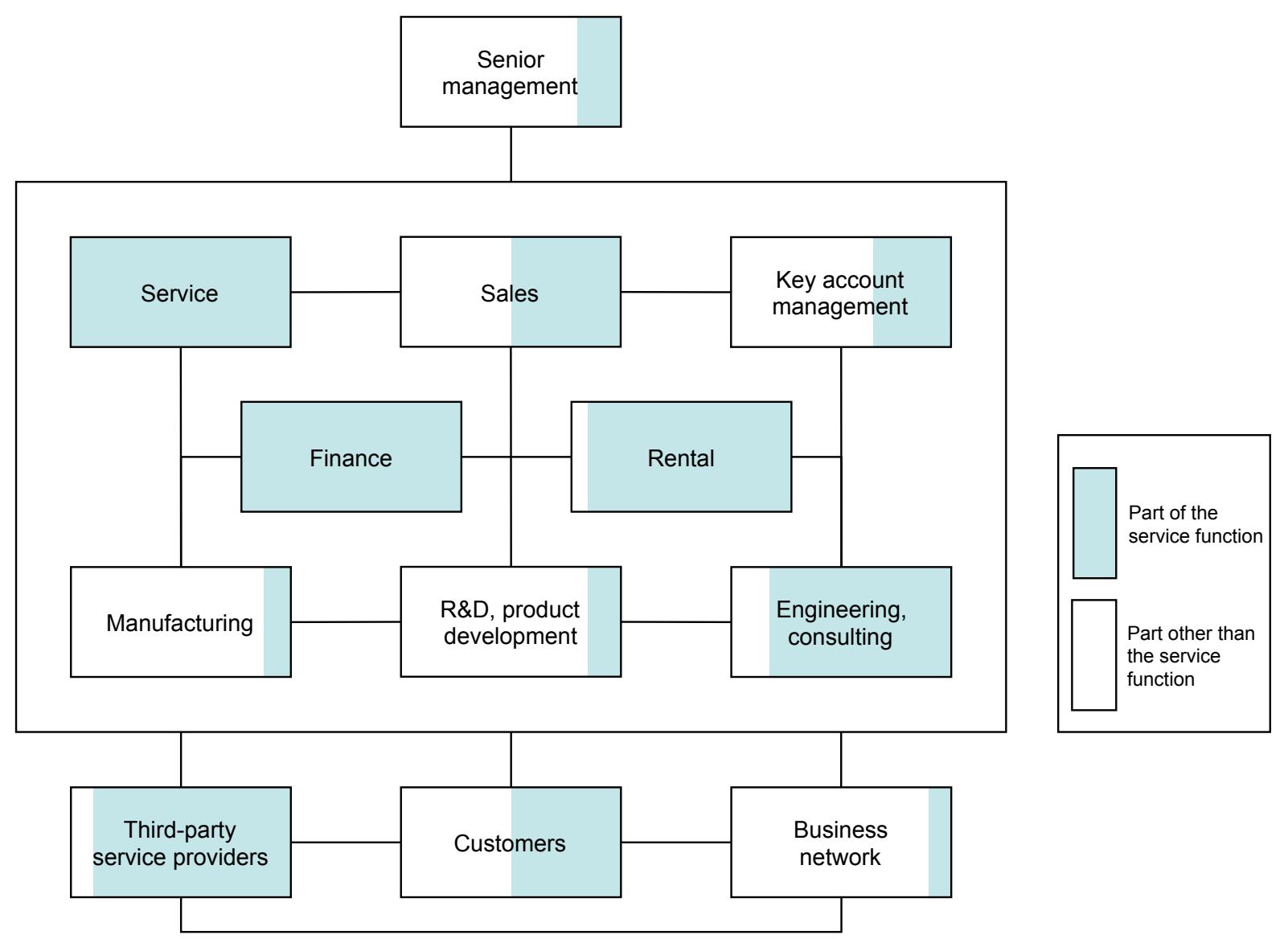

Figure 1. An example of a firm's service function. 